\title{
Dust Deposition Effect on Solar Photovoltaic Modules Performance: A Review
}

\author{
*Muhammad Ismail Jamali, Ghullam Mustafa Bhutto, Abdul Sattar Saand, Mohsin Ali Koondhar, \\ Abdul Qadeer Tunio \\ Department of Electrical Engineering Quaid-e-Awam University of Engineering, Science and \\ Technology Nawabshah \\ *Corresponding Author: engrismail@quest.edu.pk
}

\begin{abstract}
The power generation everywhere in the world is mostly generated from nonrenewable technology source particularly fossil fuel. So, these resources will be reduced to utilizing in future. Among these power generation technologies, Photovoltaic (PV) system have got great position by several reasons. This paper gives general review of PV module performance and effect of dust deposition. The deposition of dust has significant effect in transmittance of solar irradiation in the PV module. The dust deposition effect of multiple areas is discussed in literature review.
\end{abstract}

Keywords- PV module, Dust deposition effect, Cleaning technique

Date Received 21-09-2020

Date Accepted 24-10-2020

Date Published 18-12-2020

\section{INTRODUCTION}

$\mathrm{T}$ HE renewable energy application is an interesting area for research. This trend is driven by rising fossil Fuel price, concerns about air quality, human health and its impact the dependence of fossil fuels on the environment [1].

PV module Technology can provide a clean alternative source over thermal generation. Saudi Arabia plans to install solar photovoltaic systems A system capable of generating 1,481 MW in four years Period of increased renewable energy production [2]. Renewable energy is uncontrollable constraints like environmental factors. The benefits of renewable energy over nonrenewable that it is environment friendly.

It is unlimited and is natural resource of energy. The disadvantage of non-conventional energy is that their limited output power conversion from solar irradiation to electrical energy, this ranges between $12 \%$ and $20 \%$ efficiency of solar module [3].

While the PV technology experience to the outdoor condition, the dust accumulation impact the efficiency of PV system. The weather parameter dust is described as a general term for any particle of matter that exist in the environment with less than 500um diameter (10times smaller to the diameter of man hair) involving but unlimited for solid inorganic and organic particles such as dust particles, smoke (involving industrial smoke, road traffic smoke and firewood smoke) volcanic vaporization, bacteria, pollen, fungi, microfibers and worn limestones $[4,5]$.

To obtain maximum advantage from pv technology, to technical losses concern to ground environmental must be alleviated. The operation loss may play a significant role in the minimizing the rate of energy \& should henceforth be lessened through improving the renewal protocol. The dust deposition or soiling is one of the basic climate dependent area losses in south asian area which adverse impact on the power output or levelized cost of energy if not optimally alleviated [6-9].

The region to region the weather is different and its impact of environment change. The dust is more in arid region and that significantly reduces the $\mathrm{pv}$ generation. In addition, a huge potential growth of PV technology in Pakistan, while the detailed studied for dust deposition is still not reported [10]. The soiling accumulation on the module may affect output power of PV Module by decreasing of quantity of solar irradiation falling on PV module [11].

The structure and size dispersal of soil particles depend on local weather condition \& importance, the effect of soil accumulation on pv technology power change from one city to another city [12-13]. For instance, $30 \%$ reducing output power of pv module due to soil is stated in Kuwait for a length of 38days [14]. Furthermore, a research reveals that in gulf area shows a 50pc loss in $\mathrm{PV}$ o/p power for an outdoor environment for 6months [15], while for few regions, the loss of output power could be as high $80 \%$ [16]. The other literature review reported the significant negative effect in power loss $[17,18]$. Dust accumulation theoretical modelling of predicting performance was carried of many researchers [19-21]. 


\section{LITERATURE REVIEW}

This research work is carried out, some theoretical methodologies were reviewed by viewing at various research journals, conference, proceedings, research articles, books and internet to study the work done by other researchers. In this study main PV electrical characteristic, different technologies specifications with the main performance factor and dust gathering effect on efficiency of Photovoltaic module and climatic condition. The review of research is given below:

\section{A. PV Module}

The unique link technology is divided into two categories: crystalline silicon and thin film technology. Multi-link technology is currently being researched and processed to increase the efficiency of photovoltaic modules and increase the sensitivity of the sunlight spectrum to cover any wavelength of incident radiation. Figure 1 shows the main components of the PV module assembly; they are as follows.

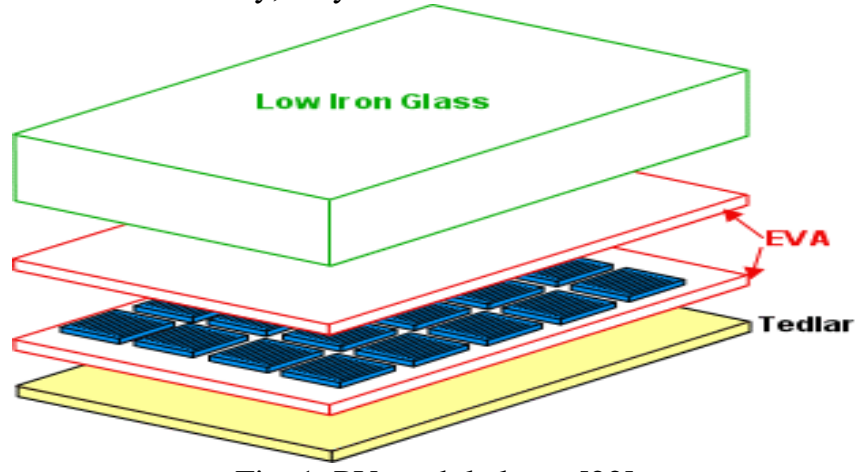

Fig. 1. PV module layer [22]

\section{a. Front Surface}

Front panel of the PV module is composed of a glass cover having high conduction and low reflection capacity at wavelength of bright sunlight. Iron normally small crystal is used for low price, solid, steady, very translucent, liquid, and gas resistant.

\section{b. Encapsulant}

Encapsulant is made up of a very thin layer of EVA (Ethyl Vinyl Acetate) at the front and back surface to assembled cells of Module, iti s constant at unlike operating temperatures and visible with low thermal resistance.

c. PV Cells

$\mathrm{PV}$ cell is playing main role to produce the power.

\section{d. $\quad$ Posterior Surface}

Backside of PV Module is madeup of Tedlar substantial low thermal resistance.

\section{A. Photovoltaic Technologies}

The available technology in the market trend is given as follows.

\section{a. Transparent}

The performance of crystalline or silicon-based photovoltaic cells is better than that of silicon core cells, and the service life is longer, and the efficiency will be reduced when the operating temperature is higher.

\section{b. Monocrystalline}

After a complicated manufacturing process, single-crystal photovoltaic cells are the oldest and most efficient silicon wafers.

\section{c. Polycrystalline}

Polycrystalline photovoltaic modules are inexpensive than monocrystalline. The entire panel is resembled with monocrystalline. To rise the productivity of the total module, large square cells must be used, the cost of the module will be less because a smaller number of cells are used.

\section{Thin film Technology}

Thin film technology illustrates the $2^{\text {nd }}$ generation of PV. Owing less manufacture constituents and less energy consumption, it is inexpensive than crystalline. It is understandable that thin film technology is characterized by lower battery thickness, semiconductor consumption and main energy, and as in the case of crystal batteries, thin film batteries are not insufficient for standard chip sizes. [22].

\section{a. Amorphous Silicon}

Silicon is accumulated in very thin layers on materials such as metals, glass or even plastics. This technique is not preferred for surface mounting because of its lower efficiency per unit area, and it causes more space consumption than using crystalline silicon [22].

\section{b. Copper Indium Selenium}

It is the most effective thin film. CIS compounds are also often mixed with CIGS or sulfur, and are not as disposed to sunny starvation as amorphous silicon.

\section{c. Cadmium Telluride}

It has lowest production cost among thin film technologies. As compare to Amorphous technology, it does not suffer any initial degradation.

\section{d. Micromorphous Tandem Technology}

Micromorphous silicon module technology joins microcrystalline and amorphous silicon together to improve the performance of the module; Microcrystalline cells have similar optical properties as crystalline cells. Micromorphous cell has the ability to respond to a wide band of the wavelength of the solar spectrum, and efficiency could reach 9.1\%. Light-induced degradation is very low in comparison with amorphous cells.

\section{PV Characteristics}

There are of two types PV system; one module or array system with and without grid connected system. The main dissimilarity between these two types is storage, in off-grid system produced electrical energy is stored in batteries while in on-grid systems produced energy is directly transferred to the public grid utility. Nowadays, on-grid systems are installed 
more often Investing in Photovoltaic also helps to reduce greenhouse gas emissions. European countries also Feed-intariff. "Net metering" mechanism was introduced in USA. Figure 2 represents the different PV system uses.

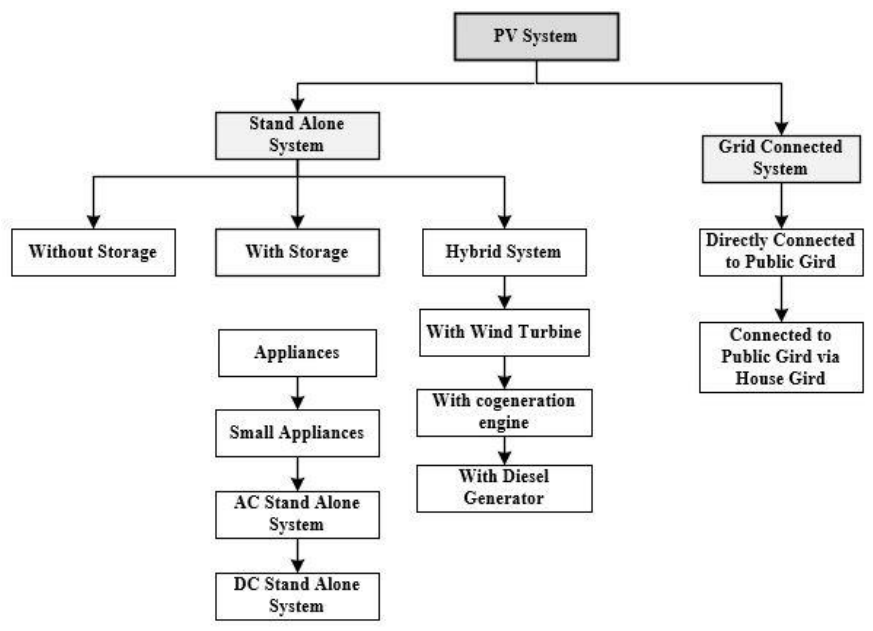

Fig. 2. Photovoltaic Applications [22]

Following are the main characteristics of photovoltaic system.

\section{a. Irradiation effect}

It is affected by irradiation of the occurrence in power of the photovoltaic system. Short circuit current (Isc) is linearly comparative to the irradiation in PV system, Voc rsiased exponentially with the rise in irradiation of the accident, and it differs slightly with the intensity light.

\section{b. $\quad$ Fill factor $(F F)$}

The FF of the PV panel illustrates the area of the major rectangle contained in the $\mathrm{I}-\mathrm{V}$ curve. FF is related to the output power, high $\mathrm{FF}$, greater the output power.

\section{c. $\quad$ PV Module efficiency $(\eta)$}

It can be calculated by equation 1 .

$\eta=\left[\frac{V_{m p} \times I_{m p}}{G \times A}\right] \times 100$

\section{d. Performance factors}

Yield of the photovoltaic module depends on several factors during conversion such as weather conditions, which affect incident irradiation, fabrication and electrical specification of PV modules.

\section{e. Optical loss}

The output power of the PV cell reduced due to irradiation of the incident must cope with any obstruction i-e translated and absorbed by the glass cover, EVA and ARC layers before reaching the PV cells. The disadvantage of optical loss is instigated by interfering $\mathrm{b} / \mathrm{w}$ air and glass protection [22].

\section{E. Electrical Terminology}

PV panel's electrical parameters discussed below.

\section{a. Short Circuit Current (Isc)}

The quantity of current produced by PV module at normal circumstances, equivalent to $0 \mathrm{~V}, \&$ so power is zero.

\section{b. Open Circuit Voltage (Voc)}

In Voc of PV Panel is measured on no-load condition. The terminal voltage is directly measured from multimeter.

\section{c. $\quad$ Maximum or Peak Power (Pmax)}

The maximum power is calculated as follows Pmax $=$ Voc $*$ Ioc

\section{d. Current at Maximum Power}

The measure of current provided to the unit at greatest power under ordinary standard. It is utilized, the evaluated current of the PV.

\section{e. $\quad$ Voltage at Maximum Power}

Supply voltage of instrument when the Pmax. range value under normal standard. It is utilized as insignificant voltage of the instrument.

\section{f. $\quad$ Maximum System Voltage}

The Vmax. applied to PV cells of the system.

\section{g. $\quad$ Fill Factor $(F F)$}

The power is divided that may be supplied to a load to the products of the Voc and Isc [22].

T. Bhattacharya et al [23] conducted research to different meteorological parameters have considerable influence on the production of PV power. Dust accumulation is one of major term which reduce the terminal power. To get the maximum output from solar PV panel that must be clear panel without dust. The efficiency slowly and gradually decreases over the passage of time for dusty environment.

Muhammad Anser Bashir, et al [24] conducted research in Taxila, Pakistan for the PV modules of three different types and technology were carried out. Results were showed that the with increasing temperature the module efficiency effected. The experimental setup was positioned in outdoor condition of weather. The temperature and solar radition was finding out, the solar radation was directly proportional to efficiency of module but inversely proportional to the rise of temperature from standard condition.

Jose Cano [25] Conducted research about the soiling losses on PV modules and found that there are also partial field data 
studies about the subject. The study showed the importance of investigating the effects of tilted position on dust. The research also contains couple of sets of small modules. One-to-one of the sets has 9 Photovoltaic panels which are tilted at angles; $0^{\circ}, 5^{\circ}$, $10^{\circ}, 15^{\circ}, 20^{\circ}, 23^{\circ}, 30^{\circ}, 33^{\circ}$ and $40^{\circ}$. The first set is termed "Cleaned". It was cleaned each second day. The remaining set was not clean through out the research study.

F. Mani et al [26] specify the association between the output power, solar radiations and dust particle size structure of dirty PV panels. Dust used in synthetic dust tests were collected from different region of India, sieve investigation is used to find the comparative \%age of normal particle sizes. Power and Irradiance are procured utilizing relapse ex-amination indicating the impact of molecule size piece existing on the board. Further, the inclination plot for most extreme force extraction is resolved for each dirty panel and the deviation from the ideal tilt edge of a spotless panel is detected.

Michael Gostein et al [27] have examined that deposition of dust and other environmental contaminants on photovoltaic panels, have a major cause of lost potential power by photovoltaic installations. To improve the modeling of performance or to optimize the washing should be held regularly basis. Currently, measurement device is available based on the amount of the two coplanar PV panels; from which one is commonly clean other in nature accumulate ecological contaminants.

\section{E. Effect of Climate and Environmental Factors}

Laith Sa'd Basha [22] The author reveals that Photovoltaic system performance depends on mainly weather parameters such as ambient temperature, incident irradiation and thermal characteristic of the PV system technology.

\section{a. Temperature effect}

Ambient temperature effect Module temperature, as PV module temperature increases short-circuit current rises a little other than the STC temperature. When temperature of panel exceeds 25 cent degree, the open circuit voltage will be greatly unnatural, in other words, it will decrease the power $\mathrm{o} / \mathrm{p}$ from the PV module.

\section{b. Hot/Warm air effect}

The thermal reaction of photovoltaic modules is the main factor that interferes with current generation. The photovoltaic unit receives incident radiation; part of it is converted into electrical energy according to the efficiency of the device. The rest of the event radiation heats the PV panel increases the working temperature relative to the warm capacity of the PV material.

$$
\text { c. } \quad \text { Aging }
$$

It decreases the output power among life time of PV panel, it is significant issue for the stockholders for future research in PVarea.

d. Wind
Speed and direction of wind is affecting the temperature of PV Panel. Through convection heat transfer PV panel can be cooled. If speed of wind low it will increase convection heat transfer, and decrease panel temperature based on arrangement for the PV system.

\section{e. Snow}

It affects on PV Panel in winter as well as summer season in hilly area. As compare to inclined module horizontal module has greater disclosure the snow [22].

\section{f. $\quad$ Dust and Dirt}

It has been noticed early in summer as compared dry season that, dirt and dust have lower edges of the panel.

This can cause difference $\mathrm{b} / \mathrm{w}$ measured and predict values because dust not counted in simulation [22].

Darwish et al [28] author reveals that dust decrease the performance and efficiency of PV system. The gathering of dust on the upper layer of Photovoltaic panel decreases its performance.

S. Mekhilef et al [29] author reveals that the material and design factors, in future, there are various common factors which affect the PV modules performance for instance humidity, dust and air velocity.

Hamdy K. Elminir et al [30] demonstrates a complete untried study on environmental factors effects on the efficiency \& electrical power o/p of PV panels. Distinctive circumstances, incidence point of view, angle of inclination, direction of unit, temperature is measured the main environmental parameters.

Swapna Roy et al [31] An experiment conducted on the clearance of carbon dust on the photovoltaic panels and its impact on the output power is studied. It finds out that plant carbon can reduce the efficiency of the system, plus the partial shadow effect.

D.K. Chaturvedi et al [32] this study is based on the study of influences that affect the performance of the photovoltaic system in real time for example, long shadow trees standing near the PV plant, shadow the other parallel line of the panel etc. Rating of panel is degrading by key factor of dust. In this research temperature manipulate, actual power and current of panel also considered.

Rajeshwari Bhol et al [33] stated in their research; Operation of a PV panel has revealed that their stability and competence depend on various aspects. The $\mathrm{o} / \mathrm{p}$ of PV panel is generally precious by unlike environmental feature such as dirt, blush, illumination and shading.

Yassine Charabi et al [34] This research presents a unique approach to combining the effects of temperature and dust by carrying large PV plants using fuzzy logic and evaluating multiple spatial GIS criteria.

Tiago D.L. Soares et al [35] the purpose of this study to analyze photovoltaic systems taking into account the different atmospheric conditions. Data on the actual production of different photovoltaic technologies has been studied as well as meteorological data from the experiment of the laboratory of Sun, own by EDP, in four different geographical places in continental Portugal. 
AvijitSaha et al [36] reveals that the environmental effects on solar PV module performance through P-spice simulation based on experimental data. Through PSpice simulation, it has been found that the overall efficiency of PV solar energy decreases considerably with the generation of hot spots owing to the accumulation of soil and partial shading of solar panels.

Farid Touati et al [37] in this research of the cuase of dirt, temperature and relative moisture are calculated based on the energy efficiency of monocrystalline silicon and amorphous PV cells. Investigational consequences demonstrated that the efficiency of monocrystalline photovoltaic cells is as high as $85 \%$, while the efficiency of amorphous photovoltaic cells is $70 \%$. For these two technologies, the influence of dust deposition is far greater than the influence of relative moisture and air temperature. However, the energy efficiency of single crystal modules shows that the degradation rate of dust exposure is about $10 \%$ faster. For some time, amorphous PV cells have been affected by temperature rise $\&$ relative moisture rise above $40^{\circ} \mathrm{C}$ and $22 \%$ correspondingly.

\section{F. Causes of Dust \& Soiling on PV Module}

Helene Berg Pedersen [38] The author reveals that how accumulation of dust and soil affects the optical values of glass surfaces being used in photovoltaic modules, in the Nordic climate.

Monto Mani et al [39] reveals that an approximation at present research scenario by carefully studying dust effect on Photovoltaic system efficiency and identifying experiments with respect to more relevant study was estimated.

Rajput et al [40] reveals that the dust effect decreases the output power and efficiency of PV modules. It was found that the highest effectiveness of clean module is 6.38 percentages and minimum is 2.29 percentages. Instead, the maximum efficiency of dusty module is $0.64 \%$ age and minimum is $0.33 \%$. Consequently, the results show that dust effectively lowers down the production power by $92.11 \%$ and the said efficiency by $89 \%$.

A.A. Kazem et al [41] reveals that the dust causes, types and conditions of dust as main to analysis its effects on PV system. The dust and dust storm is highly affect the performance of PV modules.

Elizabeth Boykiw [42] author, in the end, has concluded that the region is gifted with one of the maximum solar radiation densities in the entire world. The dust deposition is one of the major obstacles to the optimized radiations on the solar collectors. Dust decreases the performance of the PV Modules. Shaharin A. Sulaiman et al [43] various studies those showed that the performance of solar panels is reduced because of accumulated dust on them, but the results were unclear. The objective of this study was to identify solar PV panel's performance and to study the dust effects deposition on them. In order to find the resulting electrical power efficiency and production various experiments were carried out by taking dust atoms on PV panels with constant-power sunny input. It was noticed during study carried out that gathered soiling on the layer of PV panel may lower down the efficiency of the system up to 50.

Abhishek Rao et al [44] conducted research on solar PV panel performance. It is affected by high temperature of cell, soiling, disparity and other balance-of-system related losses. Soiling mainly depends upon installation conditions, is a complex work efficiency issue to appropriate quantify.

T. Sarver et al [45] gave a complete summary of soiling problems can be seen in this paper, primarily those which are related to dust and joint dust moisture conditions that are characteristic to the number of the most solar-rich geographic locations around the globe.

A. Sayyah et al [46] conducted research to the power plants; moreover, undergo from two major weather degrading issues: firstly, high ambient temperature \& secondly, towering attention of atmospheric dust. Poverty of solar concert of collectors is caused by soiling. Thus, it results in a significant loss energy produce in all solar plants worldwide.

S. A.M. Said et al [47] study includes the outcome of dust fouling on the entire plane goblet transmittance, spectral transmittance of anti reflective layered glass \& classification of the substantial and chemical properties of dust particles. A part from this, micro-adhesion forces of dust particles on flat glass substrates is also additional. The final results showed a 20 percentages cutback in glass conduction \& a $5 \mathrm{~g} / \mathrm{m}^{2}$ of dust collection on the glass surface of PV panel slanted at an angle $26 \&$ exposed to sun for 45 days.

Ndiaye et al [48] reveal that the key purpose of the study is to determine the cause of dust on the performance of PV modules. The main focus on variation of electrical characteristic due to dust. Pmax, Imax, Isc and FF are affected parameter of Solar PV module due to dust increases on its layer. The maximum $\mathrm{o} / \mathrm{p}$ power loss of the polycrystalline module \& mono crystalline module was found 18 to $78 \%$ individually. Imax loss was varying from 23 to $80 \% \mathrm{pc}-\mathrm{Si}$ and $\mathrm{mc}-\mathrm{Si}$ modules for individually.

Hassan Qasem et al [49] the effect of dust is quantifying by the particle size as a sample: short wavelength, high light is transmittance due to effect of small size particle. Wider band gap pv technology is mostly affected than small band gap. The impact of falling dust i.e effected the overall performance with time period unless it is cleaned by hand. The angle of inclination keep as higher as dust deposition low.

M. Saidan et al [50] The author reveals that the study is carried out in Baghdad city located in Iraq, was on the dust deposition effect on Solar PV modules. Losses was quantified by increasing dust on the surface of PV modules. The dust was deposited on three like modules. The dust density and size distribution were also analysis by sensitive aerosols measuring system. The dust particle increase on the surface was result to decrease both Isc and output power as compare to clean module parameters. the average rate of reduction of the efficiencies of the solar modules viewing to dust are; $6.24,11.8$ and $18.74 \%$ calculated for experience periods of a day, a week and a month. Massi Pavan et al [51] reveals that the performances were compared of two $1 \mathrm{MW}$ solar gardens before and after a whole cleanup of the PV panel at normal test environments like, solar radiation $1000 \mathrm{~W} / \mathrm{m} 2$. The consequences were shown in this study indicate that how the pollution influences both the type of the soil and the washing technique effect the losses. The researchers planted on sandy soil lost $6.9 \%$, while plants planted on denser soil lost $1.1 \%$.

C. Schill et al [52] author reveals that the performance of the modules over the specific period of time is examined by 
monitoring the feature of IV curve each 10 minute. The visible modules' soiling could be viewed by chance because of construction of buildings nearby a test site located on the Gran Canary Island, West of Morocco in the Atlantic Ocean. It was decided only to clean the irradiation sensors and not to clean the PV modules. The reduce of the output of the power and the efficiency over time were recorded in order to examine the soiling influences. Thus, within the 5 months the efficiencies dropped to $20 \%$ age of the early values.

F.A. Mejia, J. Kleissl et al [53] the author reveals that the dust causes the drop-in efficiency of PV system. The average dust loss per day is $0.051 \%$, and a total of $26 \%$ of sites are greater than $0.1 \%$ per day. The dust loss is greater in places with an inclination angle, and the area difference is not statistically shown.

E. Suresh Kumar et al [54] discuss the incomplete survey information about soiling losses on PV cell, increase of sand \& dirt particles from the outdoor environment on PV Cells decrease the generated output power. This research is an understanding loss caused by the deposition of dust on the layer of PV panels to observe \& compute such losses based on the experiments showed by various researcher's in the world.

N.W. Alnaser et al [55] discover that in the MENA area dust deposits on the surface of PV cell is one of the main causes for poor performance of PV system. This research on the effects of dirt on energy production by the PV system $500 \mathrm{kWp}$ mounted at the institute of Bahrain. The concentration of the deposited dirt varies from 5-12gram per $\mathrm{m}^{2}$, with a typical decrease in power to $40 \mathrm{pc}$ of the maximum available.

M. Catelani et al [56] purpose of this research is to determine the efficiency by monitoring a single PV module in as reference panel and the statistical technique is used. In specific the issue linked to efficiency decreases due to the existence of dirt and contamination on the layer of the PV module has been considered. The cause of ecological representatives in terms of variation MP were investigated.

Pathik Chamaria et al [57] have shown dust particles or the minute is affected by the angle of tilt of solar collectors, exposure period, weather site wind properties of motion and dust.

Mohammadreza Maghami et al [58] illustrate the results of research carried out on the evaluation of two fix Flat photovoltaic (FFP). One module that has been cleaned several times and others is the "dusty module" that was not cleaned during this study. The results of this study show that too much power and energy decrease due to the dust deposited on the surface. The contribution of this work with another study has been done is that they calculate the loss of power in tropical climate which forces with several days of rain.

Liza Boyle et al [59] gathered evidence that the accumulation of dust on the PV panels were reduced the power o/p of the PV panel. The dust can accumulate on glass panels in the commercial city of Colorado, such as those used for photovoltaic cladding panels. These plates are detected in the environment to change the span and collect various amounts of dust at several tilt angles. For dust growth less than $1.5 \mathrm{~g} / \mathrm{m} 2$, the light transmittance is reduced by $6 \% / \mathrm{g} / \mathrm{m} 2$ dust accumulations. In addition, the data shows that the incident angle does not affect the drop in transmittance due to dust deposition.
Malay K. Mazumder et al [60] this document provides a brief review of the demand for a new transparent electrodynamic screen (EDS) technology to remove dust, as often as required, from waterless solar collectors. Power o/p is sustained $>90 \mathrm{pc}$ contrasted to that of the module under clean conditions. Dust removal efficiency is greater than 90 percentages with test dust samples from unusual arid zones and the energy consumption for EDS operation is less than 0.03 cycle $\mathrm{Wh} / \mathrm{m} 2 /$ cleaning. Loredana Cristaldi et al [61] the author reveals that PV panel appropriate for these applications is in effect as well as a simple procedure for the credentials of its parameters. Serious problems related to the measurement and evaluations of the required quantity of environmental are analyzed as well as their main metrological requirements.

C. A. Belhadj et al [62] the author reveals that studying performance about PV generator using Cassy system environment. Two photovoltaic panels have been exposed to harsh weather situations such as high temperature, moisture, fairly high irradiation and often high dust accumulation. The measurement system clearly showed the effect of dust, high temperature and variations of irradiation on PV panel efficiency attesting to its demand for research and educational purposes. F. Mejia et al [63] have identified that soiling is the deposition of dust on the solar modules which results in a reduction in the optical efficiencies of the CSP systems. Soiling losses were found $0.21 \mathrm{pc} /$ day. The site was experimental a reduce in efficiency from 7.2-5.6pc throughout a without moisture period of 108 days in summer at which point an accident rain that most improved efficiency lost decreasing to $7.1 \mathrm{pc}$.

Emad Talib Hashim et al [64] said that the practice of solar energy in Iraq faces many problems; One of these is the deposition of "dust on the surface of the solar module" which would be very low its efficiency. The outcome of dust deposits on the fixed installation of solar modules with different angles inclined $15^{\circ}, 33^{\circ}, 45^{\circ}$ and $60^{\circ}$. Evaluation of the performance of solar modules in different situations like rain, wind and humidity are measured in the study of the effect of dust on the performance of the solar module.

K. Dastoori et al [65] The authors reveal that factors that affect the functional or operational efficiency of solar panel for instance: deposit dirt on the layer, PV material; Covering; angle of inclination of the panel; Positioning of PV panel \& module temperatures. This research focuses on the study of the effect of stimulating dirt atom on the performance of the PV panel.

\section{G. Cleaning Technique for Removal of Dust}

The removal of dust accumulation on solar module surface can be done by implementing various methods, which are,

- Mechanical

- Electromechanical

- $\quad$ Electrostatic

- $\quad$ Physical-chemical

Akram Abdul Ameer et al; [66] conducted research is to how the Soiling and\& dust collection decrease the transitivity. This show a clear view for the study about the manipulate of dirt collection on PV panel performance \& a argument for some remedies method applied in the previous conducted studies.

J.K. Kaldellis et al [67] carried out experimental measurements inside assured period of time $\&$ the influence of the unlike dust 
accumulation on thickness on the energy produce $\&$ the costeffective routine of the small power station is evaluated.

Sravanthi Boppana et al [68] purpose of this article is to discuss the new working method towards the progress of a standardized method of artificial fouling for photovoltaic (PV) coatings. In this study, poly-si mini-modules and mono-Si forms were dirty and characterized by I-V, reflectance and quantum efficiency (QE) to calculate the effect of soiling on performance.

Ali Assi et al [69] recognize that sand molecules tend to occur slowly on the PV layer creates difficulties in the dusting process. Dust accumulation reduces the efficiency of the PV panel owing to the mutual effect of shading \& hotness. It is a unique process to minimze the effect of dust and soil and increase the temperature on photovoltaic systems to the PV arrays are defined.

L. Cristaldi et al [70] the author reveals that the efficiency reduced due to increase dust on PV module surface. This study provide calculation for both effect aging and dust deposition. The planned for future is approached to identify the losses of energy production due to aging of PV module by the losses due to present of dust accumulation on PV modules surface.

H.Problem Statement

- $\quad$ The environment factors that effect the performance of PV module.

- The deposition of dust on PV module has an adversative impact on transmittance of irradiation in PV module.

- High temperature and dust make layer of dust irremovable.

- $\quad$ Rain and storm make the PV Module dirtier.

- The Humidity is stronger the layer of dust.

- The Nawabshah weather has high ambient temperature that adverse impact on PV module efficiency.

\begin{tabular}{|c|c|c|c|c|}
\hline Reference & Area & Period & $\begin{array}{l}\text { Dust } \\
\text { Density }\end{array}$ & Power Reduction \\
\hline [71] & Pakistan & $\begin{array}{l}3 \\
\text { Months }\end{array}$ & $1 \mathrm{mg} / \mathrm{cm}^{2}$ & $\begin{array}{l}\text { Monocrystalline: } 20.0 \% \\
\text { and Polycrystalline: } \\
16.0 \%\end{array}$ \\
\hline [72] & Pakistan. & $\begin{array}{l}3 \\
\text { Months }\end{array}$ & $\begin{array}{l}0.8 \\
\mathrm{mg} / \mathrm{cm} 2, \\
0.7 \\
\mathrm{mg} / \mathrm{cm} 2 \\
\text { and } \quad 0.7 \\
\mathrm{mg} / \mathrm{cm} 2\end{array}$ & $\begin{array}{l}\text { Polycrystalline: } \\
\text { June } 22.0 \% \text {, } \\
\text { July } 16.0 \% \text { \& } \\
\text { Aug } 18.0 \%\end{array}$ \\
\hline [73] & Iran & $\begin{array}{l}2 \\
\text { Months } \\
\& \quad 10 \\
\text { days }\end{array}$ & $6.1 \mathrm{~g} / \mathrm{m}^{2}$ & $21.5 \%$ \\
\hline [74] & $\begin{array}{l}\text { Saudi } \\
\text { Arabia }\end{array}$ & $\begin{array}{l}6 \\
\text { Months }\end{array}$ & & $50.0 \%$ \\
\hline [75] & China & & $22.0 \mathrm{~g} / \mathrm{m}^{2}$ & $26.0 \%$ \\
\hline [76] & India & & $\begin{array}{l}1.4 \mathrm{~g} / \mathrm{m}^{2} \\
7.155 \\
\mathrm{~g} / \mathrm{m}^{2}\end{array}$ & $\begin{array}{l}5 \text { to } 6.0 \% \\
45 \text { to } 55.0 \%\end{array}$ \\
\hline
\end{tabular}

\section{CONCLUSION}

The overall literature review showing that the dust is main factor which reduce the efficiency of PV system. the dust density increased in arid region mostly in large amount that effect the PV output. In order to get maximum efficiency from PV module that it must keep regularly clean.

Table 1. Dust quantifying and power loss of pv module

\section{REFERENCES}

[1] S. A. M. Said, G. Hassan, H. M. Walwil, N. Al-Aqeeli, "The effect of environmental factors and dust accumulation on photovoltaic modules and dust-accumulation mitigation strategies", Renewable and Sustainable Energy Reviews, 82, pp. 743-760, 2018.

[2] A. Baras, W. Bamhair, Y. Alkhoshi, M. Alodan, "Opportunities and challenges of solar energy in Saudi Arabia”, World Renew Energy Forum, 4721, 2012.

[3] T. M. Razykov, C. S. Ferekides, D. Morel, E. Stefanakos, H. S. Ullal, H. M. Upadhyaya, "Solar photovoltaic electricity: current status and future prospects", Sol Energy, vol. 85, no. 8, pp.1580-1608, 2011.

[4] Y. N. Chanchangi, A. Ghosh, S. Sundaram, T. K. Mallick, "Dust and PV Performance in Nigeria: A review", Renewable and Sustainable Energy Reviews, 121, 109704, 2020.

[5] Z. A. Darwish, H. A. Kazemb, K. Sopian, M. A. Al-Goul, H. Alawadhi, "Effect of dust pollutant type on photovoltaic performance", Renew Sustain Energy Rev, 41, pp. 735$744,2015$.

[6] A. Ullah, A. Amin, T. Haider, M. Saleem, N. Z. Butt, "Investigation of soiling effects, dust chemistry and optimum cleaning schedule for PV modules in Lahore, Pakistan", Renewable Energy, 150, pp. 456-468, 2020.

[7] G.A. Nadh, S. Vijay, A. Gupta, "Investigation ON the effects OF dust accumulation, transmittace on glass plates and performance OF mono and poly crystalline silica modules", International Journal Renew. Energy Resour, vol. 4, no. 3, 628-634, 2004.

[8] A. M. Al-Sabounchi, S. A. Yalyali, H. A. Al-Thani, "Design and performance evaluation of a photovoltaic grid-connected system in hot weather conditions", Renew. Energy, 53, pp. 71-78, 2013.

[9] A. O. Mohamed, A. Hasan, "Effect of dust accumulation on performance of photovoltaic solar modules in Sahara environment", J. Basic Appl. Sci. Res., vol. 2, no. 11, pp. 1103011036, 2012.

[10] Statistics, P.B.o, "Population Census of Major Cities of Pakistan", 2017 cited 2020; Available from: http://www.pbs.gov.pk/content/population-census.

[11]S. A. Said, et al., "The effect of environmental factors and dust accumulation

on photovoltaic modules and dust-accumulation mitigation strategies", Renew. Sustain. Energy Rev., 82, pp. 743-760, 2018.

[12]H. Imran, Z. Maqsood, A. Ullah, \& N. Z. Butt, "Effective Prediction of Transmission of Solar Irradiance through Dusty Solar Panels using Atmospheric Aerosol Data for Lahore, Pakistan", In 46th IEEE Photovoltaic Specialists Conference, pp. 2889-2893, 2019.

[13]J. Kaldellis and M. Kapsali, "Simulating the dust effect on the 
energy performance of photovoltaic generators based on experimental measurements," Energy, vol. 36, no. 8, pp. 5154 5161, 2011.

[14] A. Sayigh, S. Al-Jandal, and H. Ahmed, "Dust effect on solar flat surfaces devices in Kuwait," in Proc. of the workshop on the physics of non-conventional energy sources and materials science for energy. ICTP Triest, Italy, 1985, pp. 353-367.

[15] M. J. Adinoyi and S. A. Said, "Effect of dust accumulation on the power outputs of solar photovoltaic modules," Renew. Energ., vol.

pp. 633-636, 2013.

[16] M. El-Shobokshy, A. Mujahid, and A. Zakzouk, "Effects of dust on the performance of concentrator photovoltaic cells," IEE Proceedings I (Solid-State and Electron Devices), vol. 132, no. 1, pp. 5-8, 1985.

[17] A. M. El-Nashar, "Effect of dust deposition on the performance of a solar desalination plant operating in an arid desert area," Sol. Energy, vol. 75, no. 5, pp. 421-431, 2003.

[18] A. M. Pavan, A. Mellit, and D. D. Pieri, "The effect of soiling on energy production for large-scale photovoltaic plants," Sol. Energy, vol. 85, no. 5, pp. 1128-1136, 2011.

[19] C. Katzan and J. Edwards, "Lunar dust transport and potential interactions with power system components," NASA contractor report, pp. 1-42, 1991.

[20] J. Zang and Y. Wang, "Analysis of computation model of particle deposition on transmittance for photovoltaic panels," Energy Proced., vol. 12, pp. 554-559, 2011.

[21] L. Xingcai and N. Kun, "Effectively predict the solar radiation transmittance of dusty photovoltaic panels through LambertBeer law," Renew.Energ., vol. 123, pp. 634-638, 2018.

[22] Laith Sa'd Basha(2012) "analysis and evaluation tools development of photovoltaic modules and system performance under Jordanian and German climat icconditions" Faculty of Engineering at Cairo University

[23] T. Bhattacharya, A. K. Chakraborty, and K. Pal, "Influence of Environmental Dust on the Operating Characteristics of the Solar PV Module in Tripura, India", International Journal of Engineering Research, vol. 4, no.3, pp. 141 - 144, 2015.

[24] M. A. Bashir, H. M. Ali, S. Khalil, M. Ali, and A. M. Siddiqui, "Comparison of Performance Measurements of Photovoltaic Modules during Winter Months in Taxila, Pakistan", International Journal of Photoenergy, pp.1-8, 2014.

[25] J. Cano, "Photovoltaic Modules: Effect of Tilt Angle on Soiling", Master thesis Arizona State University, 2011

[26] F. Mani, S. Pulipaka, R. Kumar, "Characterization of power losses of a soiled PV panel in Shekhawati region of India", Solar Energy, 131, pp. 96-106, 2016.

[27] M. Gostein, B. Littmann, J. R. Caron, L. Dunn, “Comparing PV Power Plant Soiling Measurements Extracted from PV Module Irradiance and Power Measurements", 39th IEEE Photovoltaic Specialists Conference (PVSC), Tampa, FL, 2013.

[28] Z. A. Darwish, H. A. Kazem, K. Sopian, M. A. Alghoul and M. T. Chaichan, "Impact of Some Environmental Variables with Dust on Solar Photovoltaic (PV) Performance: Review and Research Status", International journal of energy and environment, 152, 2013.

[29] S. Mekhilef, R. Saidur, M. Kamalisarvestani, "Effect of dust, humidity and air velocity on efficiency of photovoltaic cells", Renewable and Sustainable Energy Reviews, 16, pp. 2920-2925, 2012.
[30] H. K. Elminir, V. Benda, J. Toǔsek, "Effects Of Solar Irradiation Conditions And Other Factors on the Outdoor Performance Of Photovoltaic Modules", Journal of Electrical Engineering, vol. 52, no. 5-6, pp.125-133, 2001.

[31] S. Roy, "Impact of Carbon Dust Particle Deposition and Partial Shadow ofPV Array", Electrical Engineering Department, Netaji Subhash Engineering College Techno City, Garia, Kolkata, India, 2014.

[32] D. K. Chaturvedi, S. Sharma, "An Experimental Study and Verification of the Facts Related to Factors Affecting the Performance of Solar Pv Systems", Fifth International Conference on Communication Systems and Network Technologies, 2015

[33] R. Bhol, A. Pradhan, R. Dash, S. M. Ali, "Environmental Effect Assessment On Performance of Solar PV Panel", International Conference on Circuit, Power and Computing Technologies, 2015.

[34] Y. Charabi, A. Gastli, "Integration of temperature and dust effects in siting large PV power plant in hot arid area", Renewable Energy, 57, pp.635-644, 2013.

[35] T. D. L. Soares, “Analysing productivity in Photovoltaic systems under different atmospheric conditions", Mestrado Integrado em Engenharia F'1sica Tecnol'ogica Instituto Superior T'ecnico, Lisboa, Portugal, 2014.

[36] A. Saha, N. N. Nipu, Md. F. Khan, "PSpice Based Study of Environmental Effect on the Performance of the Solar PV Module", 4th International Conference on the Development in the in Renewable Energy Technology, 2016.

[37] F. Touati, M. Al-Hitmi, H. Bouchech, "Towards Understanding the Effects of Climatic and Environmental Factors on Solar PV Performance in Arid Desert Regions (Qatar) for Various PV Technologies", First International Conference on Renewable Energies and Vehicular Technology, 2012.

[38] Kjeller, H. B. Pedersen, "Experimental study of soiling on photovoltaic modules in a Nordic climate", Master thesis, 2015.

[39] M. Mani, R. Pillai, "Impact of dust on solar photovoltaic (PV) performance: Research status, challenges and recommendations", Centre for Sustainable Technologies, Indian Institute of Science, Bangalore 560012, India, 2010.

[40] D. S. Rajput, K. Sudhakar, "Effect of Dust on the Performance of Solar PV Panel", International Journal of ChemTech Research, vol. 5, no.2, pp. 1083-1086, 2013.

[41] A. A. Kazem, T. M. Chaichan, A. H. Kazem, "Dust effect on photovoltaic utilization in Iraq", Renewable and Sustainable Energy Reviews, 37, pp. 734-749, 2014

[42] E. Boykiw, "The Effect of Settling Dust in the Arava Valley on the Performance of Solar Photovoltaic Panels", Department of Environmental Science Allegheny College Meadville, Pennsylvania, 2011.

[43] A. S. Sulaiman, H. H. Hussain, N. S. H. N. Leh, and M. S. I. Razali, "Effects of Dust on the Performance of PV Panels", International Scholarly and Scientific Research \& Innovation, vol. 5, no. 10, 2011

[44] A. Rao, R. Pillai, M. M. P. Ramamurthy, "Influence of dust deposition on photovoltaic panel performance", Energy Procedia, 54, pp. 690 - 700, 2014.

[45] T. Sarver, A. Al-Qaraghuli, L. L. Kazmerski, "A comprehensive review of the impact of dust on the use of solar energy: History, investigations, results, literature, and mitigation approaches", Renewable and Sustainable Energy Reviews, 22, pp. 698-733, 
2013.

[46] A. Sayyah, M. N. Horenstein, M. K. Mazumder, "Energy yield loss caused by dust deposition on photovoltaic panels", Solar Energy, 107, pp.576-604, 2014.

[47] S. A. M. Said, H. M. Walwil, "Fundamental studies on dust fouling effects on PV module performance", Solar Energy, 107, pp. 328-337, 2014.

[48] A. Ndiaye, C. M. F. Kébé, P. A. Ndiaye, A. Charki, A. Kobi and V. Sambou, "Impact of dust on the photovoltaic (PV) modules characteristics after an exposition year in Sahelian environment: The case of Senegal", International Journal of Physical Sciences, vol. 8, no. 21, pp. 1166-1173, 2013.

[49] H. Qasem, "Effect of Accumulated Dust on the Performance of Photovoltaic Modules", Doctoral Thesis, Philosophy of Loughborough University, 2013.

[50] M. Saidan, A. G. Albaali, E. Alasis, J. K. Kaldellis, "Experimental study on the effect of dust deposition on solar photovoltaic panels in desert environment", Renewable Energy 92, pp. 499-505, 2016.

[51] A. M. Pavan, A. Mellit, D. D. Pieri, "The effect of soiling on energy production for large-scale photovoltaic plants", Solar Energy 85, pp.1128-1136, 2011.

[52] C. Schill, S. Brachmann, M. Koehl, "Impact of soiling on IVcurves and efficiency of PV-modules" Solar Energy, 112, pp.259-262, 2015.

[53] F. A. Mejia, J. Kleissl, "Soiling losses for solar photovoltaic systems in California”, Solar Energy, 95, pp. 357-363, 2013.

[54] E. S. Kumar, Dr. B. Sarkar, D. K. Behera, "Soiling and Dust Impact on the Efficiency and the Maximum Power Point in the Photovoltaic Modules", International Journal of Engineering Research \& Technology, vol. 2, no. 2, pp.1-8, 2013.

[55] N. W. Alnaser, A. A. Dakhel, M. J. A. Othman, I. Batarseh, J. K. Lee, S. Najmaii, W. E. Alnaser, "Dust Accumulation Study on the Bapco 0.5MWp PV Project at University of Bahrain", International Journal of Power and Renewable Energy Systems, vol. 2, no. 1, pp.1-54, 2015.

[56] M. Catelani, L. Ciani, L. Cristaldi, M. Faifer, M. Lazzaroni, M. Rossi, "Characterization of Photovoltaic Panels: The Effects of Dust" 2nd IEEE Energycon Conference \& Exhibition / Advances in Energy Conversion Symp, 2012.

[57] P. Chamaria, A. Dube, Dr. Ruchika, A. P. Mittal, "Consequences of Dust on Solar Photovoltaic Module and Its Generation", 6th IEEE International Conference on Power Electronics India, 2014.

[58] M. Maghami, H. Hizam, C. Gomes, "Impact of Dust on Solar Energy Generation based on Actual Performance", IEEE International Conference Power \& Energy, 2014.

[59] L. Boyle, H. Flinchpaugh, M. Hannigan, "Impact of Natural Soiling on the Transmission of PV Cover Plates", University of Colorado, Boulder, Colorado, United States, 2013.

[60] M. K. Mazumder, M. N. Horenstein, C. Heiling, "Environmental Degradation of the Optical Surface of PV Modules and Solar Mirrors by Soiling and High RH and Mitigation Methods for Minimizing Energy Yield Losses", 42nd IEEE Photovoltaic Specialist Conference, 2015.

[61] L. Cristaldi, M. Faifer, M. Rossi, S. Toscani, M. Catelani, L. Ciani, M. Lazzaroni, "Simplified method for evaluating the effects of dust and aging on photovoltaic panels", Measurement 54, pp. 207-214, 2014.

[62] C. A. Belhadj, S. E. Ahmed, and M. Kassas, "PV Generator Performance Using Cassy System", International Conference on

[125]
Renewable Energy Research and Applications, 2013.

[63] F. Mejia, J. Kleissl, J. L. Bosch, "The effect of dust on solar photovoltaic systems", Energy Procedia, 49, pp. 2370-2376, 2014.

[64] E. T. Hashim, T. A. Hussien, "Dust Effect on the Efficiency of Silicon Mono Crystalline Solar Modules at Different Tilt Angles at Al-Jadryia Climate Conditions", Journal of Engineering, vol. 22, no. 2, pp. 56-73, 2016.

[65] K. Dastoori, G. Al-Shabaan, M. Kolhe, D. Thompson, B. Makin, "Charge Measurement of Dust Particles on Photovoltaic Module", The 8th International Symposium on Advanced Topics in Electrical Engineering the Faculty of Electrical Engineering, U.P.B., Bucharest, 2013.

[66] A. A. A. Al-Khazzar, "A New Method to Reduce Soiling Effect on Performance of a Solar PV Module", International Journal of Advance Research and Innovation, vol. 3, no. 4, pp. 601-606, 2015.

[67] J. K. Kaldellis, A. Kokala, "Quantifying the decrease of the photovoltaic panels' energy yield due to phenomena of natural air pollution disposal", Energy, 35, pp.4862-4869, 2010.

[68] S. Boppana, V. Rajasekar, G. TamizhMani, "Working towards the Development of a Standardized Artificial Soiling Method", Arizona State University Photovoltaic Reliability Laboratory, Arizona, United States, 2015.

[69] A. Assi, A. Hassan, M. Al-Shamisi, H. Hejase, "Removal of Air Blown Dust from Photovoltaic Arrays Using Forced Air Flow of Return Air from Air Conditioning Systems", IEEE Conference Publications, pp.1-5, 2012.

[70] L. Cristaldi, M. Faifer, M. Rossi, F. Ponci, "A Simple Photovoltaic Panel Model: Characterization Procedure and Evaluation of the Role of Environmental Measurements", IEEE Transactions on Instrumentation and Measurement, vol. 61, no. 10, 2012.

[71] H. M. Ali, M. A. Zafar, M. A. Bashir, M. A. Nasir, M. Ali, \& A. M. Siddiqui, "Effect of dust deposition on the performance of photovoltaic modules in Taxila, Pakistan”, Thermal Science, vol. 21, no. 2, 915-923, 2017.

[72]Z. Abbas, K. Harijan, P. Hameed, \& F. Bhayo, "Effect of dust on the performance of photovoltaic system (a case study of Quaid-E-Azam Solar Park Bahawalpur, Pakistan)", Noble International Journal of Scientific Research, vol. 1, no. 6, 73-79, 2017.

[73] A. Gholami, I. Khazaee, S. Eslami, M. Zandi, \& E. Akrami, "Experimental investigation of dust deposition effects on photo-voltaic output performance”, Solar Energy, 159, pp. 346-352, 2018.

[74] M. J. Adinoyi, \& S. A. Said, "Effect of dust accumulation on the power outputs of solar photovoltaic modules", Renewable energy, 60, pp. 633-636, 2013.

[75] B. Zhao, S. Zhang, S. Cao, \& Q. Zhao, "Cleaning cycle optimization and cost evaluation of module dust for photovoltaic power plants in China", Clean Technologies and Environmental Policy, vol. 21, no. 8, pp. 1645-1654, 2019.

[76] A. Rao, R. Pillai, M. Mani, \& P. Ramamurthy, "Influence of dust deposition on photovoltaic panel performance", Energy Procedia, 54, pp. 690-700, 2014.

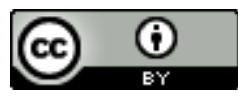

Journal of Applied and Emerging Sciences by BUITEMS is licensed under a Creative Commons Attribution 4.0 International License. 